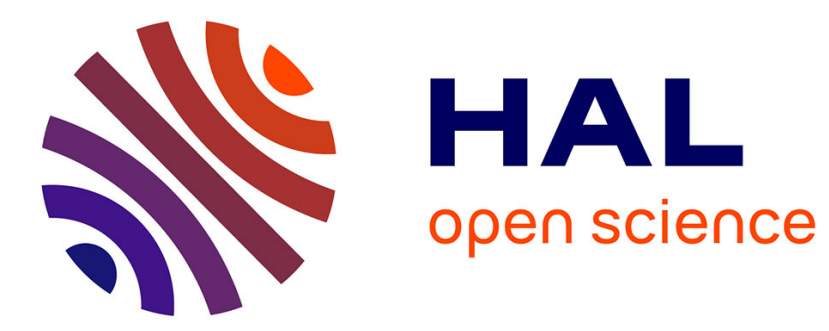

\title{
Return migrants: The rise of new entrepreneurs in rural China
}

\author{
Sylvie Démurger, Hui Xu
}

\section{To cite this version:}

Sylvie Démurger, Hui Xu. Return migrants: The rise of new entrepreneurs in rural China. 2010. halshs-00477241

\section{HAL Id: halshs-00477241 https://shs.hal.science/halshs-00477241}

Submitted on 28 Apr 2010

HAL is a multi-disciplinary open access archive for the deposit and dissemination of scientific research documents, whether they are published or not. The documents may come from teaching and research institutions in France or abroad, or from public or private research centers.
L'archive ouverte pluridisciplinaire HAL, est destinée au dépôt et à la diffusion de documents scientifiques de niveau recherche, publiés ou non, émanant des établissements d'enseignement et de recherche français ou étrangers, des laboratoires publics ou privés. 
Return migrants : The rise of new entrepreneurs in rural China

Sylvie Démurger, Hui Xu

Avril 2010 


\section{GATE Groupe d'Analyse et de Théorie Économique Lyon-St Étienne}

93, chemin des Mouilles 69130 Ecully - France

Tel. +33(0)4 72866060

Fax $+33(0) 472866090$

6, rue Basse des Rives 42023 Saint-Etienne cedex 02 - France

Tel. +33 (0)4 77421960

Fax. $+33(0) 477421950$

Messagerie électronique / Email : gate@gate.cnrs.fr

Téléchargement / Download : http://www.gate.cnrs.fr - Publications / Working Papers 


\title{
Return migrants: The rise of new entrepreneurs in rural China*
}

\author{
Sylvie Démurger ${ }^{\mathrm{a}, \mathrm{b}} \&$ Hui $\mathrm{Xu}^{\mathrm{a}, \mathrm{c}^{*}}$
}

March 2010

\begin{abstract}
This paper analyzes return migrants' occupational choice upon their return to their home village, by using an original rural household survey conducted in Wuwei county (Anhui province, China) in 2008. We apply two complementary approaches: a horizontal comparative analysis of occupational choice between non-migrants and return migrants, and a vertical investigation of the impact of migration experience on returnees only. Two main findings are drawn up from the estimation of probit models which account for potential selection bias and endogeneity. First, return migrants are more likely to be self-employed and to opt for higher ability jobs than non-migrants. Second, both return savings and the frequency of job changes during migration increase the likelihood for return migrants to become self-employed. These findings suggest that (a) working experience during migration enhances individual's human capital and entrepreneurial ability, and (b) repatriated migration experience is a key stimulating factor in promoting rural entrepreneur activity.
\end{abstract}

Keywords: Return migrants, occupational change, entrepreneurship, Asia, China.

JEL classification: O15, J62, L26, O53.

\footnotetext{
* This paper has benefited from financial support from the Région Rhône-Alpes (France) and from the "Household registration system reform and urban population management innovation study" project of the Center for Modern Chinese City Studies (CCMC) at the East China Normal University. We are especially grateful to Ding Jinhong for precious help and advice and to Pr. Sun Zhongfeng and Anhui University for helpful assistance on the survey. We would also like to thank Wuwei local officials for their support and help during the field work, and Flemming Christiansen, Florence Goffette-Nagot and Quang Nguyen for useful discussions on earlier versions of the paper.

${ }^{a}$ Université de Lyon, Lyon, F-69003, France; CNRS, GATE Lyon St Etienne, UMR 5824, 93, chemin des Mouilles, Ecully, F-69130, France; ENS-LSH, Lyon, France.

${ }^{\mathrm{b}}$ CNRS, CEFC, USR 3331 Asie Orientale, Hong Kong.

${ }^{\mathrm{c}}$ Center for Modern Chinese City Studies (CCMC), East China Normal University, Shanghai, China.

* Corresponding author. E-mail addresses: demurger@gate.cnrs.fr (S. Démurger), hui.xu@ens-1sh.fr (H. Xu)
} 


\section{Introduction}

China's rapid economic development and government policy changes towards higher inter-regional labor mobility have encouraged a massive rural-urban labor force exodus since the mid-1980s. The National Bureau of Statistics estimates the total number of rural migrants working in cities in 2008 to be about 140 million. Estimations also indicate that among the rural labor force, every fifth person is a rural migrant, and that about one-half of the rural population lives in households with one or more migrant workers.

The migration phenomenon in China has several peculiarities that make it quite specific as compared to international experience. First, it is largely an internal movement, from rural to urban areas, and given the size of the Chinese population, flows of rural migrants to cities are taking place on a massive scale. Second, the migration phenomenon itself has been shaped by strong institutional constraints, including the complex and inter-related systems of household registration $(\mathrm{Hukou})^{1}$ and rural land tenure. Most rural migrants working in cities still hold a rural Hukou, and as a consequence, they are denied access to urban social welfare, including healthcare, schooling for their children, social insurance, etc. However, their rural Hukou entitles rural migrants the right for arable land in their native village and as such plays the role of a safety net by "protecting them from being landless, jobless and homeless" (Huang and Zhan, 2005, p. 79). These administrative barriers to permanent settlement in cities tend to make rural migrants more likely to both maintain close ties with their village of origin and return to their home community within several years. A large part of rural migrants in China are therefore temporary migrants.

Temporary migration can take various forms depending on whether or not the migrants settle back permanently upon return. Seasonal or circular migration, with back and forth movements between rural and urban $\operatorname{areas}^{2}$, is a somewhat well-documented phenomenon in China, with a number of studies focusing on issues such as the determinants of migration decisions (Hare 1999; Zhao 1999a, 1999b; Zhu 2002) or the impact of migrant remittances on rural development (Giles 2006; Rozelle et al. 1999; Taylor et al. 2003). As rural-urban migration itself did not occur on a large scale until the mid-1980s, return migration with permanent resettlement in home areas is a much newer phenomenon that still needs to be explored ${ }^{3}$. Although there is no systematic estimation of the actual number of return migrants all over China, various estimations converge towards about one-third of all migrants

\footnotetext{
${ }^{1}$ The household registration system, established in 1958, imposes that every Chinese citizen is registered according to his place of residence (rural versus urban) and occupation (agricultural versus non-agricultural). It is a "de facto internal passport system" (Knight and Song, 2005) that confers different legal rights to residents. In villages, residents are given rights to land for farming and housing while in cities, residents are given rights to a package of social benefits and access to urban jobs.

${ }_{2}$ The usual return period for rural migrants in China is the Chinese New Year break, during which rural migrants return to their hometown for a short stay before leaving again.

${ }^{3}$ Still, several papers have studied return migration and its impact on sending communities, mostly with data collected on specific areas at the end of the 1990s. See Hare (1999), Ma (2001; 2002), Murphy (2002), Wang and Fan (2006), and Zhao (2002).
} 
having returned to their home community by the end of the 1990s (Murphy, 2002; Zhao, 2002). A research project directed by the Chinese Ministry of Agriculture from 1997 to 2001 indicates that return migrants represent about $6.3 \%$ of the whole rural labor force and $28.5 \%$ of the total migrant population (Gao and Jia, 2007). It also highlights an increasing trend to return, especially after the mid-1990s.

As pointed out by Laczko (2005), research on internal migration and its impact on the development of source communities has somewhat been eclipsed by the twin debate on international migration. Nonetheless, following the renewed interest on this issue fostered by the New Economics of Labor Migration (NELM) literature (e.g. Stark and Bloom, 1985), there is a mounting agreement on the channels through which internal migration can actually contribute to rural development. Migration can be viewed as a strategy for rural households to diversify income sources so as to reduce risks and smooth their income (Ellis, 1998). In this context, remittances sent by migrants to their rural families are expected to help securing income and alleviating poverty in rural areas. As for China, Du et al. (2005) find that having a migrant increases a household's income per capita by 8.5-13.1 per cent. However, the overall impact on poverty is found to be modest because most poor people do not migrate. Moreover, depending on how remittances are used, their "safety net" impact may be on a short-term or a long-term basis. For the specific case of China, evidence is mixed. On one hand, Taylor et al. (2003) find mild evidence that households invest remittances in self-employed activities. On the other hand, Huang and Zhan (2005) argue that remittances are used more for consumption than for investment and as a consequence, they can only be expected to have a short-term impact on poverty reduction ${ }^{4}$.

Another channel through which migration can influence rural development is return migration. A recent literature on international migration focusing on migrants' occupational change upon return has highlighted the propensity of returnees to become self-employed upon return (e.g. Dustmann and Kirchkamp, 2002; Ilahi, 1999; Martin and Radu, 2009; McCormick and Wahba, 2001; Mesnard, 2004; Piracha and Vadean, 2010; Wahba and Zenou, 2009). Indeed, with a working experience outside their original hometown, return migrants are likely to bring back accumulated human, social and financial capital that can enable them to start their own business upon return and benefit their village of origin. As mentioned above, research on return migration in China remains limited despite a mounting interest on the issue. A few empirical papers have studied the causes and consequences of return migration on individual datasets mainly collected at the end of the $1990 \mathrm{~s}^{5}$. Regarding the impact of

\footnotetext{
${ }^{4}$ De Brauw and Rozelle (2008) confirm this result on rural household data collected in 2000. They find no evidence of a relationship between migration (measured by both the number of household members in the migrant work force and the number of return migrants) and productive investment.

${ }^{5}$ As far as the determinants of return migration are concerned, Hare (1999) finds on a sample of 309 households collected in 1995 in a county in Henan province that pull factors related to the household's own-production labor needs are the most important determinants of how long migrant workers stay in cities before returning home. Using data from a rural household survey carried out in six provinces in 1999, Zhao (2002) finds evidence that both push and pull factors affect the return decision. Wang and Fan (2006), who examine the "selectivity" of
} 
return migration, Murphy (2002) highlights the contribution of migration working experience to returnees' business establishment in two counties in Jiangxi province. She finds that longer urban sojourns enable migrants not only to accumulate funds and gain management experience, but also to forge business contacts in the cities. Zhao (2002) also finds that return migrants invest twice more in productive farm assets as compared to non-migrants but she finds no evidence of returnees being more likely to participate in non-farm work than non-migrants. Closer to our research objective, Ma (2001) uses data collected in 1997 from 13 rural counties in 9 provinces and highlights the fundamental role of migration experience in return migrants' occupational change after return. In particular, he finds that it is the improvement of the migrant's skills and entrepreneurial ability rather than material accumulation during migration that facilitates the occupational mobility towards non-farm employment upon return. In a second paper, Ma (2002) also shows that social capital is an important factor in promoting return migrants' entrepreneurship activity and achieving positive economic result from their entrepreneurial activity.

Our aim here is to evaluate the role of return migration in a rural county (Wuwei county) in Anhui province that has traditionally been known as a county of a long labor export history, as well as with a large quantity of enterprises established by return migrants. Indeed, the county is famous for sending out domestic service female workers since the beginning of the $1980 \mathrm{~s}^{6}$, as well as for its application of the policy of "Feng Huan Chao" which is reported to have had a positive influence on the attraction of return migrants (Gao, 2001; Zhao, 2002) ${ }^{8}$. According to local official statistics, at the end of 2006, there were 420,000 rural migrants working outside Wuwei county, and up to 2006, about 10,000 return migrants had established their own enterprises in the county upon return (Wuwei county government, 2007).

To explore the return migrants' post-return occupational choice behaviors in Wuwei county, we consider two types of occupational change induced by return migration. We start with a comparison with non-migrants ${ }^{9}$ : do return migrants engage in different activities as compared to non-migrants because of their migration experience? Are they more likely to opt for self-employment as compared to their rural counterparts? We then turn to the benefits that returnees themselves gain from their own

return migrants with data collected in Sichuan and Anhui in 1999 predict a positive relationship between "success returnees" (who returned for investment reason) and the length of spell in the destination area, indicating that the accumulation of migration experience is positively related to the returnees' investment purpose for return.

${ }^{6}$ A popular phrase was once that "Domestic service workers in Beijing come from Anhui, while those domestic service workers from Anhui are from Wuwei".

7 The policy of "Feng Huan Chao" (i.e., attracting the phoenixes to come back to their home nest) was launched in 1996 by the county government. By offering "foreign investment" advantages, the explicit purpose of the policy is to attract local out-migrants to return and to invest in their hometown.

${ }^{8}$ Zhao (2002) cites Wuwei county as an example of counties that have actively tried to "attract back migrant entrepreneurs". Referring to field interviews, she mentions that Wuwei county has invested in "infrastructure in order to make the local investment environment more attractive to returning entrepreneurs" (p. 377).

9 This "horizontal" approach has also been used by Zhao (2002), who evaluates the different occupational choices between three groups of population in rural China. On other countries, see also Martin and Radu (2009), Piracha and Vadean (2010), and Wahba and Zenou (2009). 
migration history ${ }^{10}$ : do return migrants experience occupational mobility upon return as compared to their own position before migration? What is the role of their past migration experience in determining their current occupation?

This paper contributes to an emergent literature focusing on China's return migrant flows and their impact on rural development in at least three ways. First, by using data from a recent and original rural household survey conducted in Wuwei county (Anhui province) in 2008, we provide an updated and novel assessment of return migrants' occupational mobility in China. As highlighted above, most papers use data from the end of the 1990s. This trait drastically limits the scope of such analyses since return migration has sharply increased over the 2000s. Moreover, the dataset used in this paper covers a region not only temporally but also spatially distinct. Given the size of China, geographically focused and thorough studies can bring informative and useful insights as to how return migration may affect the development of sending communities. The choice of the county of Wuwei has been dictated by the emigration history of the county, as well as by its recent attraction of return migration. By specifically focusing on this county, we intend to contribute to a better understanding of migrants' occupational motivations upon return.

Another contribution of this paper is that it analyses occupational choice from a variety of angles. As explained above, we conduct both a comparative analysis of return migrants' occupational decisions with that of their rural counterparts, and a vertical investigation of the role of migration experience on return migrants' decision to enter entrepreneurship. While both approaches have been separately adopted in migration studies on China, no paper has provided yet any comprehensive study combining these approaches in order to assess the specific role of return migrants and their migration experience in entrepreneurship development in rural China.

Last, our paper adds to the existing literature by proposing various categorizations of rural occupations that not only distinguish farm and off-farm activities (as in Zhao, 2002), but also working ability with respect to both entrepreneurship and skill level. Our estimations not only corroborate some of the results found in the existing literature but also enrich the understanding of the conditions for stimulating rural development. To briefly summarize the key findings, return migrants are found to be more likely to opt for higher ability jobs than non-migrants, and their assets in the form of savings and migration experience are found to play a prominent role in this choice.

The remainder of the paper is structured as follows. Section 2 briefly reviews the available theory on entrepreneurship and return migration, and presents a stylized framework for the empirical part. Section 3 describes the data set used in the statistical analysis and provides descriptive statistics on occupational distribution. Section 4 examines the differences in occupational choice in rural areas between non-migrants and return migrants. Section 5 investigates the role of migration experience in

\footnotetext{
${ }^{10}$ Examples of this "vertical" approach can be found in both internal and international migration studies (Arif and Irfan, 1997; Ilahi, 1999; Ma, 2001; Mesnard 2004) that focus on the role of migration experience in the occupational mobility of return migrants.
} 
return migrant's self-employment participation. Concluding remarks are given in the final section.

\section{Return migration and entrepreneurship: theoretical considerations}

Who becomes entrepreneur and who becomes wage-worker? Is migration an important factor in determining entrepreneurial activities? This section reviews the theoretical background of entrepreneurship decision, by first focusing on a general occupational choice model and three seminal theories on the determinants of entrepreneurship. It then presents the migration literature that specifically focuses on the entrepreneurship of the migrant population.

\section{Occupational choice - A general framework}

According to models in entrepreneurship studies, the decision to enter entrepreneurship is basically an individual occupational choice decision based on a comparison of the expected payoffs between whether to become an entrepreneur or a wage worker (Kihlstrom and Laffont, 1979; Evans and Leighton, 1989; Evans and Jovanovic, 1989; Fonseca et al., 2001; Haile, 2008). In this framework, an individual takes up self-employment if her expected utility is higher, otherwise she chooses wage employment. The utilities in either occupation depend on a series of factors. Following Haile (2008)'s simple model, one may assume that the expected returns from self-employment will depend on the individual entrepreneurial ability $a$, risk aversion attitude $b$, access to capital $K$, and a vector $X$ of observable personal characteristics associated with occupational choice (such as education, age, gender, socio-economic background). The expected utility from wage work will depend on job productivity (measured by the wage rate $w$ ), and individual tastes and preferences $X$.

The expected utility function for both self-employment and wage work can therefore be written as $E\left(U_{S E}\right)=f(a, b, K, X)$ and $E\left(U_{W}\right)=f(w, X)$, in which $E\left(U_{S E}\right)$ is the expected utility for self-employment and $E\left(U_{W}\right)$ the expected utility for wage work. It is also assumed that individuals receive no utility from being unemployed and/or being out of the labor force, i.e. $E\left(U_{u}\right)=E\left(U_{\text {olf }}\right)=0$. Under these assumptions, an individual will enter self-employment if $E\left(U_{S E}\right)>$ $E\left(U_{W}\right)$; otherwise, she will choose to be a wage worker.

This simple framework has its historical roots in various occupational choice models which have explored different factors in determining the decision to be entrepreneur (Parker 2005). In the following paragraphs, we present three seminal models that emphasize different aspects in the entrepreneurship decision.

\section{Innate entrepreneur ability theory}

A first group of papers focuses on the innate entrepreneurial ability $a$. This unobservable entrepreneurship characteristic is generally considered as an exogenous factor in determining 
entrepreneurship. The invisible ability is given at birth and it differs across individuals. The emphasis on the innate entrepreneur ability as an important factor of entrepreneurship can be dated back to Lucas (1978). He argues that the heterogeneous characteristics of this innate talent determine the variation of a manager's income. Untalented managers are more likely to become wage workers and most able entrepreneurs would run the largest firms.

In line with Lucas (1978), Fonseca et al. (2001) also argue that the choice of entrepreneurship is governed by an exogenous entrepreneurial ability. They interpret this ability as an ability to create and manage jobs. Different individuals have different entrepreneurial ability levels. Each worker is born with it and carries it for the rest of her life. Suppose $V$ is the expected present-discounted value of income of a vacant job to an entrepreneur and $U$ the expected present-discounted value of income to an unemployed worker. Suppose also that both $V$ and $U$ are independent of the entrepreneurial ability parameter $a$, but they depend on a series of labor market characteristics such as job productivity, the wage sharing rule and market tightness. $K$ is a fixed cost the individual has to pay for starting up a business. Fonseca et al. (2001) demonstrate that entrepreneurs are those individuals whose $a$ satisfies the inequality: $a V-K \geq U$. If $S=\frac{U+K}{V}$ represents the "reservation entrepreneurial ability", the individual will start up a business if her entrepreneurial ability $a$ exceeds $S$. Otherwise she will choose to be a wage worker.

\section{Risk aversion theory}

The second seminal entrepreneurial model on the determinants of entrepreneurship lies on the individual's psychological characteristics, such as risk aversion. The basic idea is that entrepreneur activities are determined by individual's risk attitude. Those who are less risk averse are more likely to be entrepreneurs as opposed to wage workers. The emphasis on risk characteristic has its historical roots in the work of Knight (1921) and has been formally developed by Kihlstrom and Laffont (1979) in their competitive general equilibrium theory of the firm under uncertainty. Their theoretical model is also based on the assumption of a utility maximization in the choice between entrepreneurship and wage employment. While recognizing that many factors can influence this choice, they focus specifically on risk aversion as a key determinant in their framework. When labor supply equals labor demand, a unique labor market equilibrium can be reached in which the individual makes her occupational decision by evaluating the uncertainty of wages determined simultaneously by the choice of the other labor market participants. As such, risk attitude becomes a determining factor in the individual occupational decision making. The less risk-averse individuals become entrepreneurs, while the more risk-averse become wage workers.

In line with this theoretical prediction, Cramer et al. (2002)'s empirical test gives clear evidence of the negative effect of risk aversion on entrepreneurship selection. They use as a proxy for individual's risk attitude the price that individuals declare being willing to pay for a ticket in a 
hypothetical lottery.

\section{Liquidity constraint theory}

The third major contribution in entrepreneurship theory is the theory of liquidity constraint. We follow the framework developed by Evans and Jovanovic (1989). Relying on the same utility maximization assumption, they specifically integrate the tightness of the liquidity constraint as a parameter in the model of entrepreneurial choice, by assuming that its level restricts the total amount of available capital $K$ that is necessary to start business. The capital constraint is presented as $0 \leq K \leq \lambda z$, where $z$ is the entrepreneur's beginning-of-period wealth and $\lambda$ is a parameter for borrowing capacity that is proportional to wealth $z$. Their framework indicates that individuals face an L-shape liquidity constraint with higher constraint occurring at the moment of creation of firms and diminishing afterwards. Their prediction is supported by empirical evidence on the US showing that liquidity constraint is binding for virtually all the individuals who are likely to start a business. This result indicates that some people are involuntary stopped from becoming entrepreneur because of liquidity constraint. According to their estimation, the liquidity constraint deters 1.3 percent of the population from entering entrepreneurship.

Going back to Fonseca et al. (2001)'s theoretical framework, we can also find supporting evidence in the equation $S=\frac{U+K}{V}$ that when the start-up cost K increases, the standard for the reservation entrepreneurial ability $S$ increases. As a result, fewer individuals would satisfy the ability requirement. As a consequence the rise of $K$ discourages entrepreneurship and increases the fraction of the population who become workers. Consistent evidence can also be found in the empirical test of Blanchflower and Oswald (1998) where they use inheritance or gift as an indication of start-up capital for new business. Using various micro data from Great Britain, they find that the probability of self-employment depends positively upon whether the individual ever received an inheritance or a gift.

Thus, access to credit can be seen as a major obstacle for entrepreneurship (Wahba and Zenou, 2009) and how an individual solves the liquidity constraint problem is a key issue. One answer is that social networks (networks of relatives, friends, etc) can help ease the credit constraint (Yueh, 2008). Using data from the Egyptian labor market, Wahba and Zenou (2009) find that social networks have a significant influence on non-migrants to be entrepreneurs, but no significant impact on return migrants. One explanation is that the accumulation of human capital and physical capital compensates to some extent for the loss of social network for return migrants. Their study emphasizes the importance of human and financial capital in determining entrepreneurial activities in developing countries, but also points out the particular importance of social network when both human and financial capital are not sufficient. 


\section{Does migration experience matter?}

Entrepreneurship theories lay the foundation for understanding the behavior of entrepreneurs in general. The next question we are interested in is on how migration experience can influence the entrepreneurship decision. We rely here on a still small, but growing literature on the issue of occupational choice of migrants upon return and the determinants of their entrepreneurship activities (Dustmann and Kirchkamp, 2002; Ilahi, 1999; McCormick and Wahba, 2001; Mesnard, 2004; Piracha and Vadean, 2010; Wahha and Zenou, 2009; Woodruff and Zenteno, 2007).

In the theoretical framework of migration study, migration is considered as part of a lifetime utility maximization plan with given budget (and liquidity) constraints (Djajic and Milbourne, 1988; Galor and Stark, 1990; Dustmann, 1995). Following Borjas and Bratsberg (1996), return migration is viewed as "part of an optimal residential location place over the life cycle" (p.165), and as a consequence, migration itself is a short-term (temporary) phenomenon used as a means of promotion after return. The underlying idea is that people decide to migrate in order to accumulate a sufficiently large amount of capital of any sort (skills, human capital, savings, experience, etc.) that will enable them to start new higher-level activities after return. In this approach, the selection process is "positive" in the sense that those migrants who return have actually decided to (migrate and) return as a lifetime plan, and they take advantage of their migration experience to move to better jobs after return. Furthermore, in models of temporary migration, the optimal migration duration and the occupational choice after return are supposed to be simultaneous: the decision to be a self-employed upon return is assumed to be taken at the same time as the decision to migrate and return.

A key point in this life cycle assumption theory lies in the fact that migration experience can be thought of as a solution for the problem of liquidity constraint for entrepreneurial activities (Mesnard, 2004, Woodruff and Zenteno, 2007). Woodruff and Zenteno (2007) demonstrate both theoretically and empirically that migration networks, which are part of migration experience, are an efficient way to alleviate capital constraints and thus to increase investment and profits. Given capital market imperfection, financial accumulation can be considered as a direct solution to capital constraint in initiating enterprises upon return (Mesnard, 2004). In the presence of credit constraints, individuals who target to become self-employed will also decide on the amount of savings to accumulate in order to set up their business after return. Hence, migrants who are more likely to be self-employed upon return can also be expected to save more during migration ${ }^{11}$. Using Tunisian data, Mesnard (2004) finds that high savings as a result of migration experience do have a positive influence on the choice to be entrepreneur after return. The positive impact of accumulated savings on the decision to enter self-employment is also highlighted in other countries' case studies (Ilahi, 1999; Piracha and Vadean, 2010).

\footnotetext{
${ }^{11}$ Including the amount of return savings into the occupational choice equation is a way to test the extent to which credit constraint affects self-employment decision. The rationale is that in the absence of credit constraint, the decision to become entrepreneur would not depend on personal wealth.
} 


\section{Data and descriptive statistics on occupational distribution}

\subsection{Household survey in Wuwei}

The data used in this paper come from a series of rural households' interviews conducted in Wuwei county, Anhui province, from September to November 2008 (hereafter named "Wuwei 2008 Survey"). The county is located in the middle of Anhui province and on the north side of Yangtze River, neighboring with the second largest city of the province, Wuhu, 116 kilometers away from the capital city of Hefei. As mentioned above, Wuwei county was selected because of both its relatively long labor force export history and its active policy to encourage return migration. Four towns were chosen for the survey: Gaogou, Liudu, Dougou and Tanggou. About three administrative villages in each town and twenty households on average in each village were randomly selected. A total of 239 households were interviewed, providing information on 969 individuals with 147 returnees $(15.2 \%)$ and 192 out-migrants (19.8\%). The out-migrants proportion is broadly consistent with aggregate estimations. A national survey conducted by the State Statistical Bureau in 2000 indicates that rural migrants accounted for $15.4 \%$ of the total rural population in Anhui province (Zhang and Li, 2004).

The data was collected in a form of a questionnaire, consisting of a series of questions about both family and individual members. Individual information includes personal characteristics (e.g., age, sex, education, etc.), actual working position and incomes. For those having a migration and/or return history, their working experience during and after migration was also recorded. At the household level, the main information includes the values of productive assets such as agricultural land, both agricultural and non-agricultural productive assets, durable goods, yearly incomes, expenditures and investment in 2007. A separate administrative village survey was also conducted in each village to collect information about the general economic, geographic as well as demographic conditions in the locality.

The sample used in this paper is composed of 384 working individuals currently living in the villages. Since our focus is on occupational choice for the working population, the sample is limited to individuals aged 17 to 70 , who declared working at least part of the year with a strictly positive income $^{12}$. For the purpose of this study, we consider two groups of workers: non-migrants and return migrants. Non-migrants are those who have no working experience or a working experience of less than 6 months outside Wuwei County. Return migrants are individuals currently settled and working in the county, who have at least 6 months migration working experience outside the county. Out of the 384 individuals in the working labor force, 298 (78\%) are non-migrants and $86(22 \%)$ return migrants.

Occupation is classified into four categories with respect to the nature of occupation: the entrepreneurial ability, the skill level as well as traditional farming participation. Both individual workers and entrepreneurs are classified as "self-employed"13. Skilled workers, professional workers,

\footnotetext{
${ }^{12}$ Unpaid workers (e.g. housewife) and individuals currently waiting for a job are excluded from the sample.

${ }^{13}$ Piracha and Vadean (2010) emphasize the relevance of distinguishing individual workers (i.e. without having
} 
semi-skilled workers, managers, government employees, clerks and salesmen are all categorized as "skilled workers". Low skilled workers, apprentices, service workers as well as family cottage workers are designated as "manual workers". Individuals who undertake traditional agricultural work are grouped as "farm laborers". Since some individuals working in rural area participate into more than one occupation at the same time, we keep the occupation of a higher "status" as the main occupation ${ }^{14}$.

\subsection{Data description}

Table 1 presents summary statistics on individual and household characteristics as well as on occupational distribution by migration status. As expected, there is a clear gap in individual characteristics between non-migrants and return migrants. Non-migrants are more than 7 years older than returnees. The proportion of men among non-migrants is lower, suggesting that women are less likely to migrate (and return) than men. As far as human capital is concerned ${ }^{15}$, they are also much less educated: the proportion of non-migrants who have received no formal education is $44 \%$ while that of returnees is $27 \%$. To sum up, these descriptive results indicate that return migrants are younger and more educated male, which is consistent with evidence from Zhao (2002) and Wang and Fan (2006) ${ }^{16}$.

With regard to household characteristics, an interesting feature is that the average land endowment per person is significantly lower for return migrants who have only $0.72 m u^{17}$ per person, as compared to 1.07 for non-migrants. As the household size for returnees is similar to that of non-migrants, this smaller land endowment probably reflects land shortage rather than labor surplus for return migrants' households. It can also be interpreted either as a cause or a consequence of a higher propensity of returnees to engage in off-farm activities. As far as household characteristics are concerned, we also find some correlation between return migration and family demand, with returnees being most likely to have children at school.

Last, Table 1 exhibits important differences in occupational participation between non-migrants and return migrants. For non-migrants, participation into farm labor (50\%) is significantly higher than in any other occupation, while for return migrants, self-employment is by far the top occupation with $44 \%$ of returnees engaged in self-employment, while the proportion of returnees engaged in farm labor and in skilled work are respectively $22 \%$ and $20 \%$. Moreover, a comparison of occupational distribution across the two groups shows that return migrants are significantly more engaged in

any paid employees) and entrepreneurs (i.e. with paid employees) in estimating the role of return migration in occupational mobility. However, our data do not allow us such a distinction because of the small number of observations per category we would be left with.

${ }^{14}$ Most multiple activities involve farm labor and one off-farm activity. Among non-migrants as well as return migrants, about $23 \%$ declared having two occupations, mostly twined with farm labor.

15 As for education, we may also note that the overall education level of the surveyed population is low since less than $10 \%$ of them reached a senior high school level or above.

${ }^{16}$ There is a slight difference though with Wang and Fan (2006) who found that women are more likely to return than men, which is clearly not the case in our sample. However, this difference may simply come from the fact that our sample excludes house workers, who are mainly females.

17 One $m u$ is equal to 0.067 hectare. 
self-employment than non-migrants.

\section{Return migration and occupational change: a horizontal comparison}

To analyze the impact of return migration on occupational choice, we first focus on the decision to enter into self-employment and/or into skilled work in the village and we try to isolate the specific effect of being a returnee on this decision. We analyze separately two types of occupational choice based on different abilities that we want to emphasize: $i$ ) self-employment decision as opposed to farm work or wage work (both unskilled and skilled), which is supposed to test for a "pure" entrepreneurship ability; and ii) self-employment or skilled work decision as opposed to farm work or unskilled wage work. By putting together skilled work and self-employment, we aim at analyzing the determinants of undertaking a "higher ability" activity defined in a broad way (from a perspective of both entrepreneurship and formal skills/qualification) and at testing whether or not migration experience influences this choice. To simplify the presentation below, the empirical strategy is explained for the first type of occupational decision only, but its application to the second type is straightforward.

To start with, Table 2 provides descriptive statistics by both migration status and occupational group (as defined above) for individuals working in rural areas. First, a comparison by occupation shows that both self-employment and higher ability jobs tend to be taken by married and more educated male. Unsurprisingly, this indicates a positive selection in terms of human capital for "upper-level" occupations. As compared to non self-employment or lower ability jobs, these activities are also clearly undertaken by heads of households with fewer very young children or older members, and with less arable land endowment. Second, a comparison by migration status shows that self-employed return migrants are on average younger and much more educated male than self-employed non-migrants. They have significantly more children of school-age and a lower land endowment per person. We find similar results for the differences between return migrants and non-migrants in higher ability jobs, except that the difference in education is now non-significant. This probably comes from a composition effect since higher ability jobs include professional work such as local teachers and doctors. Non-migrants may have advantage over return migrants in participating into these professional activities ${ }^{18}$.

\subsection{Empirical approach}

The decision to engage in self-employment is postulated to reflect the underlying individual's

\footnotetext{
${ }^{18}$ In rural China, village teachers and doctors are public servants who enjoy stable salaries and a rather good social security net. Hence, people undertaking these activities have no incentive to emigrate. However, these jobs require at the same time some professional qualification in which a sufficient education background in teaching or in medicine is a must.
} 
utility from this occupation $\left(y_{i}^{*}\right)$ :

$$
y_{i}^{*}=\beta_{0}+X_{i} \beta+\varepsilon_{i}
$$

where $\varepsilon_{i}$ is assumed to be independent from $X_{i}$ and to have a standard normal distribution (Probit model). The actual decision to be self-employed is given by the following:

$$
y_{i}=\left\{\begin{array}{lll}
1 & \text { if } & y_{i}^{*}>0 \\
0 & \text { if } & y_{i}^{*} \leq 0
\end{array}\right.
$$

In the above Probit model, the vector $X_{i}$ includes individual characteristics such as age, gender, marital status, education and being the child of the household head, and family characteristics such as the number of children less than 6 , the number of children at school and land endowment per person. Three township dummies are also used to control for location differences. Finally, a "returnee" dummy variable enters the right-hand side explanatory variables to account for the fact that migration experience may influence occupational decision upon return.

We allow return migration to be potentially endogenous to self-employment decision. The rationale is that return migrants are a self-selected group with regard to unobservable characteristics such as motivation or risk aversion. These unobservable characteristics may at least partly explain that they are less risk-averse than non-migrants and therefore also more likely to be self-employed. If unobservable heterogeneity has a direct influence on both decisions, to migrate (and return) as well as to set up a business, then the return migration variable will be correlated with the error term $\varepsilon_{i}$, which will make it effectively endogenous in the selected sample. As suggested by Greene $(1998,2008)$, this unobservable heterogeneity can be captured by using a recursive bivariate Probit model ${ }^{19}$.

Estimating a recursive bivariate Probit model requires the estimation of the return migration decision together with the self-employment decision. In addition to individual and households characteristics that may influence the return migration decision, we need instruments to control for the potential endogeneity of return migration for occupational choice. As pointed out by Taylor et al. (2003), migration networks have been shown to be important drivers for individual migration decision. In communities with a history of migration, information about potential jobs in cities or costs can be shared so that it reduces out-migration related costs or uncertainties (Massey, 1990; Piracha and Vadean, 2010; Wahha and Zenou 2009). In a similar vein, we may assume that networks and home villages' history in terms of attracting back return migrants can also influence return migration, and that the current return migration flow is a function of past return migration patterns. Following Wahha and Zenou (2009) who use the share of adult male migrants in total adult male population in individual's original community as an instrumental variable for determining the identification of return

\footnotetext{
19 Two recent papers on return migration in Egypt (Wahba and Zenou, 2009) and in Eastern Europe (Martin and Radu, 2009) follow Greene (1998)'s methodology and apply a recursive bivariate Probit model to account for the potential endogeneity of return migration in entrepreneurship decision. They both find evidence of endogeneity and show that controlling for the endogeneity of migration decision may change the estimated impact of return migration on the decision to be self-employed.
} 
migration decision, we use both the number of migrants or return migrants (dropping the observed individual) in the village and in the township as proxies for a networking effect or a culture of migration. We expect that these networks have an influence on the (return) migration decision and are not correlated with the error term in the individual occupational decision, so that they can be used as identification variables. Following Coulon and Piracha (2005)'s strategy to test the identification variables, the introduction of these network proxies in the occupational choice equation provides non-significant coefficients, which enables us to use them to identify our model.

\subsection{Estimation results}

Both simple Probit models that do not allow for selection on unobservable characteristics and recursive bivariate Probit models that capture the potential endogeneity of return migration decision in occupational choice are estimated and presented respectively in Table 3 and Table 4. As shown in Table 4, we do not find evidence of any strong endogeneity problem for both decisions either to be self-employed or to take a higher ability job. Indeed, in the two cases, the estimate of $\rho$ is very small and the Wald statistic indicates that we cannot reject the hypothesis that $\rho$ equals zero. Following Greene (2008), one may argue that this result is not as counterintuitive as it seems. Indeed, the return migration decision and the occupational choice are probably correlated, but what the correlation coefficient measures here is "(roughly) the correlation between the outcomes after the influence of the included factors is accounted for" (Greene, 2008, p. 825).

The Probit estimates reported in Tables 3 and 4 all indicate that return migrants are more likely to engage in higher ability jobs as well as in self-employment than non-migrants. Moreover, for individual as well as family characteristics, the estimated coefficients are consistent with the predictions of the standard human capital model. For self-employment decision, we find that men are more likely than women to be self-employed. Married people are also more likely to engage in self-employment. This result indicates that entrepreneurial activities are probably more easily started within a family than by a single person. This is consistent with the development process of small rural enterprises in China over the last thirty years, which has not only been based on individual entrepreneur ability, but also on a strong social network. Marriage can be thought of as a channel to enlarge these networks advantages. Consistent with a life-cycle hypothesis, the effect of age is found to be non-linear: the probability of being entrepreneur increases with age only up to a threshold level, thus confirming that entrepreneurial activities are mostly taken by middle-aged people. These results are in line with the empirical literature on the determinants of entrepreneurship that finds that in general male, married and older individuals are more likely to be self-employed (Parker, 2004). On the other hand, the shortage of land at the family level acts as a constraint that pushes people out of agriculture into off-farm activities and thus increases the individual probability to be self-employed. This finding can probably be related to the land allocation system in rural China, where households are entitled a right to use, but no real property right. As a consequence, leaving a land vacant may entail a 
risk to have to return the land to the village and thus to forfeit a future income loss (Yang, 1997).

The probability to enter higher ability jobs is also positively influenced by age (with a non-linear effect), gender and marital status. Moreover, whereas the education level does not significantly affect the decision to be self-employed, we find that the higher the respondent's level of education, the greater the likelihood that he or she chooses higher ability jobs. Being the child of the household head also increases the likelihood to take higher ability jobs. Family characteristics play a role through the number of children less than 6 and land endowment per person. Again, land shortage increases the probability to engage in off-farm activities, while having very young children discourages individuals to enter higher ability jobs. An explanation may be related to the heavy economic burden that farmers have to bear in rural China, especially for the education of their children. Having young children could thus discourage them to take jobs considered as more risky.

\section{Migration experience and occupational mobility: a vertical analysis}

The above Probit estimations support the hypothesis that return migrants are more likely to be self-employed and to take higher ability jobs as compared to their rural counterparts. There are a number of explanations for the higher propensity of return migrants to be self-employed that deserve to be further explored. First, return migrants may be a selected group of individuals who have originally participated more into self-employment before migration, meaning that their present occupation would also depend on their pre-migration occupation. However, a quick look at a transition matrix on both pre-migration and post-return occupational composition for return migrants does not reveal any systematic link between present and past occupations of returnees. More specifically, Table 5 shows that before migration, $51 \%$ of individuals were in farm labor and $26 \%$ had no job (they were students, or house workers or waiting for a job). After return, we observe a sharp decrease in farm labor participation compensated by a significant increase in self-employment as well as in wage work. Among self-employed, the vast majority were either farm laborers or unemployed, and only 3 were already self-employed before migration. Arif and Irfan (1997) found similar patterns in Pakistan, with a high tendency of occupational shifts of return migrants between pre-migration and post-return, particularly towards independent activities.

Another explanation for the high propensity of self-employment participation as well as other occupational changes after return can be related to migration working experience. Stylized facts on returnees' migration experience profile by occupation status upon return corroborate this hypothesis. As depicted in Table 6, differences in migration experience between self-employed returnees and non self-employed returnees all suggest a potential relationship between migration experience, measured in terms of length of stay, accumulated working experience or accumulated savings, and occupational choice towards self-employment after return. First, returnees who became self-employed after return were on average more than 3 years younger than those who took another (mostly wage) job when they 
left their home village, while the age gap is less than 2 years upon return. The reduced age gap is consistent with much longer migration duration for the former group ( 7.55 years versus 5.60 years $)^{20}$. In fact $42 \%$ of self-employed returnees have accumulated more than 8 years of migration experience, whereas only $21 \%$ of non self-employed returnees are in this case. Interestingly, self-employed returnees have also experienced much more frequent changes in both jobs and workplaces than non self-employed returnees during migration, and they repatriated two times more savings on average $(16,263 \text { yuan versus } 8,504 \text { yuan })^{21}$. Moreover, after return, we also observe that self-employed returnees have experienced significantly more frequent job changes than their non self-employed counterparts.

The role of repatriated human capital, social capital as well as financial capital accumulated during migration has been extensively discussed in the literature that views labor migration as part of an integrated life-time plan. Following this approach, we propose to formally test the impact of migration experience on occupational choice upon return by estimating the determinants of return migrants' present choice towards self-employment.

\subsection{Empirical strategy}

In this section, we further restrict our sample to return migrants only and use an occupational choice model similar to the one presented in Section 4. We also introduce explanatory variables that account for both migration experience and post-return experience together with a series of individual and household socio-economic characteristics. Migration experience is proxied by the frequency of job changes during migration, working experience in a big city (e.g. Beijing, Shanghai, Shenzhen) and the total family members' repatriated savings upon return ${ }^{22}$. Post return experience is proxied by return duration.

As mentioned in Section 2, in models of temporary migration, return savings are considered as inherently related to migrants' return life-time plans. From a statistical point of view, it implies that repatriated savings must be considered as a potentially endogenous variable in the estimation of the return migrants' occupational choice model (Ilahi, 1999; Mesnard, 2004; McCormick and Wahba, 2001). Following previous empirical works, we consider 4 different instrumental variables to correct for the possible sources of endogeneity: i) "migration duration" (Ilahi, 1999; Dustmann, 1995); ii) "Age at first migration" (Ilahi, 1999); iii) "squared age at first migration"; and iv) "1996 return year" (Mesnard, 2004). The last instrumental variable is a binary variable which is set to equal to 1 if individual returned in the year or after 1996 and 0 if return occurred before 1996 . The choice of this

\footnotetext{
${ }^{20}$ Migration duration is the total accumulated years of migration.

${ }^{21}$ Considering that in the sample some couples have non-separable repatriated savings and that self-employed business is mostly a family business with an overall family financial contribution, return savings here are calculated as the total family members' migration savings upon return.

${ }^{22}$ One may argue that the effect of repatriated savings on self-employment decision could be non-linear (Mesnard, 2004). On our sample, specifications including higher order powers for savings did not show evidence of any non-linear effect.
} 
year as a benchmark is related to the launch of the local government policy to attract back return migrants ("Feng Huan Chao") this very year. Our data confirms a big difference in the quantity of return migrants between the periods before and after 1996. We assume that given this policy, those who returned in or after 1996 are more likely to bring back more financial assets in response to the potential benefit from a favorable economic environment.

Probit estimates using a maximum likelihood estimator to account for the potential endogeneity issue are presented in Table 7 together with standard Probit estimates. The Wald test of the exogeneity of the instrumented variable indicates that there is not sufficient information in our sample to reject the null that repatriated savings are not endogenous. Then a standard Probit regression is appropriate to estimate the magnitude of the savings effect ${ }^{23}$.

\subsection{Estimation results}

By holding all other variables constant, our estimation results show that migration experience do significantly influence the choice in favor of self-employment among return migrants. Both return savings and the frequency of job changes are significant, although work experience in a big city does not appear as significantly affecting return migrants' self-employment participation. The computation of marginal effects at mean shows that a 1,000 yuan increase in return savings (1/12 of the average repatriated savings) leads to an increase of 1.4 percentage points in the probability that a return migrant engages in self-employment. This finding that the probability to be self-employed increases with the amount of repatriated savings provides evidence of the importance of financial accumulation during migration and supports the idea that financial capability is one of the key elements in self-employment establishment. This result is in line with the comprehensive study on self-employment in rural China provided by Mohapatra et al. (2007), in which they give support to the hypothesis that greater personal wealth eases self-employment decision by relaxing financial constraints $^{24}$. It is also consistent with empirical findings on the key role of accumulated savings in self-employment choices among return (international) migrants for other countries, such as Pakistan (Ilahi, 1999), Tunisia (Mesnard, 2004) and Albania (Piracha and Vadean, 2010). Finally, this result can also be interpreted as an indication that people in rural China face credit constraints that are strong enough to prevent them from starting up businesses without preliminary personal financial assets.

Our estimations also show that a higher frequency of job changes during migration increases the probability to be self-employed after return. Three complementary explanations can be put forward. First, in the case of voluntary job mobility, changing jobs at a higher frequency can be interpreted as the sign of a relatively lower risk aversion: individuals who change jobs more often can be considered as less risk-averse individuals. Since risk loving can be a trait of entrepreneurship (Kihlstrom and

\footnotetext{
${ }^{23}$ Mesnard (2004) also finds that the exogeneity of return savings cannot be rejected in her estimations.

${ }^{24}$ The lack of financial assets has been shown to be an important impediment to self-employment in a number of studies on both developed and developing countries. See for example Evans and Jovanovic (1989) and Holtz-Eakin et al. (1994) on the US, and Paulson and Townsend (2004) on Thailand.
} 
Laffont, 1979), it is thus reasonable that returnees with a higher frequency of job changes during migration will be more likely to be self-employed after return. Second, a higher frequency of job changes can also result in the acquisition of a richer working experience accumulated through different positions, which may in turn have a positive effect on the decision to participate in self-employment activity. Third, in the case of involuntary job mobility, a higher frequency of job changes can indicate greater job insecurity during migration, which may at least partly explain why migrants would like to choose to return back and to establish their own business at home. This explanation falls in line with Evans and Leighton (1989)'s finding of men being more likely to enter self-employment when they have changed jobs frequently. They argue that it is consistent with the view of some sociologists that "misfits" are pushed into entrepreneurship.

Return duration is also found to have a significantly positive impact: migrants who returned earlier have a higher probability of being self-employed than those who came back recently. This may indicate that participation into self-employment requires a certain time of preparation. Moreover, the concave form of the effect of age is consistent with life-cycle hypothesis. Indeed, compared to young people, middle-aged people are more likely to have accumulated both financial capital and human capital, such as management skills or social network, necessary to become entrepreneur. However, above a certain age, older people are also usually more averse to risk, and this higher risk aversion reduces their probability to set up new business in the area of origin, other things equal.

We do not find evidence of any impact of education on the returnees' probability of being self-employed. Despite that self-employed return migrants have a significantly higher level of education (Table 2), formal education does not appear as an important determinant for self-employment decision. A comparison of the absence of impact of education with the significant and positive effect of migration experience highlights the importance of accumulated skills through migration rather than through pre-migration formal education in one's post-return occupational choice. This result is consistent with Ma (2001), who shows than labor-force experience rather than education is important in explaining rural occupational change.

Finally, the three township dummy variables are all strongly significant and negative, which implies that compared to the reference township (Liudu) and other things equal, those people living in the other three townships are less likely to engage into self-employment. Liudu being the poorest township in our sample, this result indicates that other things equal, self-employment may be a strategy to get out of the disadvantage of an unfavorable economic environment and of the absence of wage work opportunities

\section{Conclusion}

Using original data from a household survey carried out in Wuwei county (Anhui province, China) in late 2008, this paper examines return migrants' occupational change in rural return area. Two 
complementary angles are considered in the analysis. We first conducted a horizontal comparative study between rural non-migrants and return migrants. We then turned to the analysis of the role of individuals' migration experience in occupational choice upon return.

Key findings can be summarized as follows. The comparative analysis with non-migrants shows that return migrants are more likely to be self-employed and to opt for higher ability jobs than their rural counterparts. The higher propensity of return migrants to be self-employed is an internationally documented phenomenon, and our analysis confirms that the Chinese rural area under study is no exception. In the vein of Lucas (1978) model of entrepreneurship in which the individual's managerial or entrepreneurial talent plays a prominent role, this finding suggests that return migrants possess or have acquired through migration more entrepreneurial ability than non-migrants.

Entrepreneurship is generally recognized as a key component in the development process since it is a specialized form of human capital developed through breaking the routine (Schultz, 1990), while at the same time a scarce resource in backward rural areas where it is most needed (Ma, 2001). As a consequence, the observed higher participation of returnees into self-employment may also be important in terms of potential for rural development. By using a 20-year labor market data, Mohapatra et al. (2007) find that in Chinese rural areas, self-employment is a sign of development. Our own evidence on the higher entrepreneurship of returnees corroborates this finding and supports the view of self-employment as a positive choice against the traditional Harris-Todaro view of informal jobs arising from a negative selection. By the same token, the high propensity for return migrants to engage in higher ability jobs also reflects their skill advantage over non-migrants.

Our investigation on the determinants of return migrants' self-employment decision highlights the positive impact of both repatriated savings and the frequency of job changes during migration on this decision. These findings are consistent with Ma (2001)'s evidence of a strong positive relationship between human capital acquisition during migration and post-return occupational choice into commercial activities. By confirming the prominent role of migration experience in return migrants' occupational choice towards self-employment, our results also corroborate the idea that migration experience is a process of human and financial capital accumulation and that returnees' preference for self-employment "is a rational response to the opportunities and constraints during migration and upon return" (Ilahi, 1999).

From a local development perspective, our findings highlight the potential role that migrants can play in stimulating forces of rural development through their accumulated human and financial capital during migration. Hence, paving a favorable business environment including simplified administrative formalities to encourage migrants to repatriate and transfer both skill and entrepreneurial abilities is certainly a key policy issue. On the other hand, our findings on the role played by repatriated savings also highlight the difficulty for rural people to overcome credit constraints that hinder the start of small-scale businesses. Anecdotal evidence from face-to-face interviews conducted during the survey further supports this hypothesis. Indeed, from these interviews, financial constraint appeared as the 
biggest issue currently faced by both non-migrants and return migrants who want to engage in self-employment activities. Therefore, further effort is called for helping local people to find financial solution to establish and develop small-scale business. One such solution could be to enlarge and generalize the provision of small-scale credit loans in local financial institutions, thus giving more financial accessibility to support local small-business establishments.

\section{References}

Arif, G. M. \& Irfan, M. (1997). Return migration and occupational change: The case of Pakistani migrants returned from the Middle East. The Pakistan Development Review, 36(1), 1-37.

Blanchflower, D.G. \& Oswald, A. (1998). What makes an entrepreneur? Journal of Labor Economics, 16(1), 26-60.

Borjas, G. J. \& Bratsberg, B. (1996). Who leaves? The out-migration of the foreign-born. Review of Economics and Statistics, 78(1), 165-176.

Coulon, A. \& Piracha, M. (2005). Self-selection and the performance of return migrants: the source country perspective. Journal of Population Economics, 18(4), 779-807.

Cramer, J. S., Hartog, J. \& Van Praag, C. M. (2002). Low risk aversion encourages the choice for entrepreneurship: An empirical test of a truism. Journal of Economic Behavior \& Organization, 48, 29-36.

De Brauw, A. \& Rozelle, S. (2008). Migration and household investment in rural China. China Economic Review, 19(2), 320-335.

Djajic, S. \& Milbourne, R. (1988). A general equilibrium model of guest-work migration-the source country perspective. Journal of international economics, 25, 335-351.

Du, Y., Park, A. \& Wang, S. G.. (2005). Migration and rural poverty in China. Journal of Comparative Economics, 33(4), 688-709.

Dustmann, C. (1995). Savings behavior of return migrants-a life-cycle analysis. Zeitschrift fuer Wirtschafts- und Sozialwissenschaften, 4, 511-533.

Dustmann, C. \& Kirchkamp, O. (2002). The optimal migration duration and activity choice after re-migration. Journal of Development Economics, 67, 351-372.

Ellis, F. (1998). Survey article: household strategies and rural livelihood diversification. The Journal of Development Studies, 35(1), 1-38.

Evans, D. S. \& Jovanovic, B. (1989). An estimated model of entrepreneurial choice under liquidity constraints. Journal of Political Economy, 97(4), 808-827.

Evans, D. S. \& Leighton, L. S. (1989). Some empirical aspects of entrepreneurship. The American Economic Review, 79(3), 519-535.

Fonseca, R., Lopez-Garcia, P., \& Pissarides, C. A. (2001). Entrepreneurship, start-up costs and employment. European Economic Review, 45, 692-705. 
Galor, O. \& Stark, O. (1990). Migrants' savings, the probability of return migration and migrants' performance. International Economic Review, 31(2), 463-467.

Gao, Q. \& Jia, H. (2007). Nongmingong huiliu de yuanyin ji yingxing fenxi [Analysis on the causes and impact of return migrants]. Management of Agricultural Science and Technology (Nongye keji guanli), 26(4), 66-68. In Chinese.

Gao, F. (2001). Report on an investigation on the female return migrants in Wuwei County. Internal report, Anhui Women's Union. In Chinese.

Giles, J. (2006). Is life more risky in the open? Household risk-coping and the opening of China's labor markets. Journal of Development Economics, 81, 25-60.

Greene, W. H. (1998). Gender economics courses in liberal arts colleges: Further results. Journal of Economic Education, 29(4), 291-300.

Greene, W. H. (2008). Econometric analysis, 6th ed., NJ: Prentice Hall.

Haile, G. A. (2008). Determinants of self-employment in urban Ethiopia: Panel data based evidence. PSI Discussion Paper: 1.

Hare, D. (1999). 'Push' versus 'pull' factors in migration outflows and returns: determinants of migration status and spell duration among China's rural population. The Journal of Development Studies, 35(3), $45-72$.

Holtz-Eakin, D., Joulfaian, D. \& Rosen, H. (1994). Entrepreneurial decision and liquidity constraints. RAND Journal of Economics, 23(2), 334-347.

Huang, P. \& Zhan, S. (2005). Internal migration in China: Linking it to development. In Migration, Development and Poverty Reduction in Asia, International Organization for Migration, Geneva.

Ilahi, N. (1999). Return migration and occupational change. Review of Development Economics, 3(2), 170-186.

Kihlstrom, R. \& Laffont, J.-J. (1979). A general equilibrium entrepreneurial theory of firm formation based on risk aversion. Journal of Political Economy, 87(4), 719-748.

Knight, F. H. (1921). Risk, uncertainty and profit. Houghton-Mifflin, New York.

Knight, J. \& Song, L. (2005). Towards a labour market in China. Oxford: Oxford University Press.

Laczko, F. (2005). Introduction: Migration, development and poverty reduction in Asia. In Migration, Development and Poverty Reduction in Asia, International Organization for Migration, Geneva.

Lucas, R. (1978). On the size distribution of business firms. Bell Journal of Economics, 9, 508-523.

Ma, Z. (2001). Urban labor-force experience as a determinant of rural occupation change: evidence from recent urban-rural return migration in China. Environment and Planning A, 33, 237-255.

Ma, Z. (2002), Social-capital mobilization and income returns to entrepreneurship: the case of return migration in rural China. Environment and Planning A, 34, 1763-1784.

Martin, R. \& Radu, D. (2009). Return Migration: the experience of Eastern Europe. Paper presented at the XXIV National Conference of Labour Economics, Sassari (Italy), 24-25 September 2009.

Massey, D. S. (1990). Social structure, household strategies and the cumulative causation of migration. 
Population Index, 56(1), 3-26.

McCormick, B. \& Wahba, J. (2001). Overseas work experience, savings, and entrepreneurship amongst return migrants to LDSs. Scottish Journal of Political Economy, 48(2), 164-178.

Mesnard, A. (2004). Temporary migration and capital market imperfections. Oxford Economic Papers, $56(2), 242-262$.

Mohapatra, S., Rozelle, S. \& Goodhue, R. (2007). The rise of self-employment in rural China: development or distress? World Development, 35(1), 163-181.

Murphy, R. (2002). How migrant labor is changing rural China. Cambridge University Press.

Parker, S. C. (2004). The economics of self-employment and entrepreneurship. Cambridge University Press.

Parker, S. C. (2005). The economics of entrepreneurship: What we know and what we don't. Foundations and Trends in Entrepreneurship, 1(1), 1-54.

Paulson, A. L. \& Townsend, R. (2004). Entrepreneurship and financial constraints in Thailand. Journal of Corporate Finance, 10, 229-262.

Piracha, M., \& Vadean, F. (2010). Return migration and occupational choice: Evidence from Albania. World Development, doi:10.1016/j.worlddev.2009.12.015.

Rozelle, S., Taylor, J. E. \& De Brauw, A. (1999). Migration, remittances, and productivity in China. American Economic Review, 89(2), 287-91.

Schultz, T. W. (1990). Restoring economic equilibrium: human capital in the modernizing economy, Oxford: Basil Blackwell.

Stark, O. \& Bloom, D. E. (1985). The new economics of labor migration. The American Economic Review, 75(2), 173-178.

Taylor, J. E., Rozelle, S., \& De Brauw, A. (2003). Migration and incomes in source communities: A new economics of migration perspective from China. Economic Development and Cultural Change, 52(1), 75-101.

Wahba, J. \& Zenou, Y. (2009). Out of Sight, out of mind: Migration, entrepreneurship and social capital. IZA Discussion Paper No. 4541.

Wang, W. W. \& Fan, C. (2006). Success or failure: selectivity and reasons of return migration in Sichuan and Anhui, China. Environment and Planning A, 38, 939- 958.

Woodruff, C. \& Zenteno, R. (2007). Migration networks and microenterprises in Mexico. Journal of Development Economics, 82, 509-528.

Wuwei county government (2007). Report on the enterprises establishment of return migrants in Wuwei county. In Chinese.

Yang, D. T. (1997). China's land arrangements and rural labor mobility. China Economic Review, 18(2), 101-115.

Yueh, L. (2008). China's entrepreneurs. World Development, 37(4), 778-786.

Zhao, Y. (1999a). Labor migration and earnings differences: the case of rural China. Economic 
Development and Cultural Change, 47(4), 767-82.

Zhao, Y. (1999b). Leaving the countryside: rural-to-urban migration decisions in China. The American Economic Review, 89(2), 281.

Zhao, Y. (2002). Causes and consequences of return migration: recent evidence from China. Journal of Comparative Economics, 30(2), 376-394.

Zhang, W. \& Li, S. (2004). An analysis of the effects of labor emigration on supporting the aged family folks in rural China. Chinese Soft Science, 8, 34-39.

Zhu, N. (2002). The impact of income gaps on migration decisions in China, China Economic Review, 13(2-3), 213-30. 
Table 1 - Descriptive statistics by migration status

\begin{tabular}{|c|c|c|c|}
\hline & \multicolumn{2}{|c|}{ Mean value or $\%$} & \multirow[t]{2}{*}{ Mean test } \\
\hline & Return migrants & Non-migrants & \\
\hline \multicolumn{4}{|l|}{ Individual characteristics } \\
\hline Age & 39.6 & 47.3 & $* * *$ \\
\hline Male & $58 \%$ & $50 \%$ & NS \\
\hline Married & $87 \%$ & $87 \%$ & NS \\
\hline \# years of schooling & 5.6 & 4.5 & $* *$ \\
\hline Illiterate & $27 \%$ & $44 \%$ & $* * *$ \\
\hline Primary school & $22 \%$ & $21 \%$ & NS \\
\hline Junior middle school & $43 \%$ & $26 \%$ & $* * *$ \\
\hline Senior high or more & $8 \%$ & $9 \%$ & NS \\
\hline Spouse of the household head & $33 \%$ & $40 \%$ & NS \\
\hline Child of the household head & $13 \%$ & $12 \%$ & NS \\
\hline \multicolumn{4}{|l|}{ Occupational distribution } \\
\hline Farm labor & $22 \%$ & $50 \%$ & $* * *$ \\
\hline Manual work & $14 \%$ & $15 \%$ & NS \\
\hline Skilled work & $20 \%$ & $13 \%$ & NS \\
\hline Self-employment & $44 \%$ & $22 \%$ & $* * *$ \\
\hline \multicolumn{4}{|l|}{ Migration experience } \\
\hline \# job changes & 1.6 & - & - \\
\hline \# city changes & 1.9 & - & - \\
\hline \# years of migration & 6.5 & - & - \\
\hline \multicolumn{4}{|l|}{ Post-return experience } \\
\hline \# years since return & 5.1 & - & - \\
\hline \# job changes upon return & 1.3 & - & - \\
\hline \multicolumn{4}{|l|}{ Household characteristics } \\
\hline \# children less than 6 & 0.19 & 0.20 & NS \\
\hline \# children at school & 0.74 & 0.59 & $*$ \\
\hline \# old members (above 70) & 0.15 & 0.21 & NS \\
\hline Household size & 4.05 & 4.23 & NS \\
\hline Land per person $(m u)(2007)$ & 0.72 & 1.07 & $* * *$ \\
\hline Sample size & 86 & 298 & \\
\hline
\end{tabular}

Source: Wuwei 2008 Survey

Notes: The mean test column indicates the significance level of mean differences between return migrants and non-migrants. NS non significant; * significant at 10\%; ** significant at 5\%; *** significant at $1 \%$.

Some averages are calculated over a smaller number of observations because of missing values. We only report the total number for reference. 
Table 2 - Descriptive statistics by migration status and by occupation

\begin{tabular}{|c|c|c|c|c|c|c|c|c|}
\hline & \multicolumn{2}{|c|}{ Self-employment } & \multicolumn{2}{|c|}{ Wage or farm work } & \multicolumn{2}{|c|}{ Higher ability job } & \multicolumn{2}{|c|}{ Lower ability job } \\
\hline & $N M$ & $\boldsymbol{R M}$ & $N M$ & $\boldsymbol{R M}$ & $N M$ & $R M$ & $N M$ & $\boldsymbol{R M}$ \\
\hline \multicolumn{9}{|l|}{ Individual characteristics } \\
\hline Age & 45.80 & 39.32 & 47.67 & 39.88 & 43.57 & 38.89 & 49.26 & 40.94 \\
\hline Male & 0.60 & 0.66 & 0.48 & 0.52 & 0.69 & 0.71 & 0.40 & 0.35 \\
\hline Married & 0.97 & 0.95 & 0.84 & 0.81 & 0.89 & 0.85 & 0.85 & 0.90 \\
\hline \# years of schooling & 4.85 & 6.18 & 4.37 & 5.21 & 6.50 & 6.40 & 3.37 & 4.29 \\
\hline Illiterate & 0.37 & 0.24 & 0.46 & 0.29 & 0.24 & 0.18 & 0.55 & 0.42 \\
\hline Primary school & 0.18 & 0.16 & 0.21 & 0.27 & 0.16 & 0.20 & 0.23 & 0.26 \\
\hline Junior middle school & 0.40 & 0.47 & 0.22 & 0.40 & 0.39 & 0.51 & 0.19 & 0.29 \\
\hline Senior high or more & 0.05 & 0.13 & 0.10 & 0.04 & 0.21 & 0.11 & 0.03 & 0.03 \\
\hline Spouse of the household head & 0.38 & 0.29 & 0.41 & 0.35 & 0.28 & 0.20 & 0.47 & 0.55 \\
\hline Child of the household head & 0.03 & 0.08 & 0.15 & 0.17 & 0.15 & 0.16 & 0.11 & 0.06 \\
\hline \multicolumn{9}{|l|}{ Household characteristics } \\
\hline \# children less than 6 & 0.14 & 0.18 & 0.21 & 0.19 & 0.11 & 0.16 & 0.24 & 0.23 \\
\hline \# children at school & 0.63 & 0.95 & 0.58 & 0.58 & 0.60 & 0.80 & 0.59 & 0.65 \\
\hline \# old members (above 70) & 0.08 & 0.16 & 0.25 & 0.15 & 0.17 & 0.16 & 0.23 & 0.13 \\
\hline Household size & 3.92 & 4.03 & 4.32 & 4.06 & 4.05 & 4.09 & 4.33 & 3.97 \\
\hline Land per person $(m u)(2007)$ & 0.72 & 0.58 & 1.16 & 0.84 & 0.77 & 0.66 & 1.23 & 0.83 \\
\hline Sample size & 65 & 38 & 233 & 48 & 105 & 55 & 193 & 31 \\
\hline
\end{tabular}

Source: Wuwei 2008 Survey.

Notes: "Higher ability job" refers to skilled wage work or self-employment. "Lower ability job" refers to farm labor or unskilled wage work. NM: non-migrants. RM: return migrants. 
Table 3 - Probit estimates of rural self-employment/skill work choice

\begin{tabular}{|c|c|c|c|c|}
\hline \multirow[t]{2}{*}{ Determinants of $\mathbf{P}($ self/higher ability) } & \multicolumn{2}{|c|}{ Self-employment } & \multicolumn{2}{|c|}{ Higher ability job } \\
\hline & $\begin{array}{c}\text { Marginal } \\
\text { effect }\end{array}$ & Z-stat. & $\begin{array}{c}\text { Marginal } \\
\text { effect }\end{array}$ & Z-stat. \\
\hline $\begin{array}{l}\text { Individual characteristics } \\
\text { Return migrants }(=1) \\
\text { Age (years) } \\
\text { Age squared } \\
\text { Male(=1) } \\
\text { Married(=1) } \\
\text { Education (years) } \\
\text { Child (=1) }\end{array}$ & $\begin{array}{c}0.104 * \\
0.033 * \\
-0.000 * * \\
0.148 * * * \\
0.161 * * \\
0.000 \\
-0.107\end{array}$ & $\begin{array}{c}1.64 \\
1.73 \\
-2.24 \\
3.48 \\
2.29 \\
0.00 \\
-1.25 \\
\end{array}$ & $\begin{array}{c}0.183 * * \\
0.106 * * * \\
-0.001 * * * \\
0.291 * * * \\
0.311 * * * \\
0.041 * * * \\
0.576 * * *\end{array}$ & $\begin{array}{c}2.24 \\
4.07 \\
-4.41 \\
5.55 \\
3.58 \\
4.13 \\
4.73 \\
\end{array}$ \\
\hline $\begin{array}{l}\text { Household characteristics } \\
\text { \# children less than } 6 \\
\text { \# children at school } \\
\text { Land per person }(\mathrm{mu})\end{array}$ & $\begin{array}{c}-0.077 \\
-0.043 \\
-0.109 * *\end{array}$ & $\begin{array}{l}-1.14 \\
-1.32 \\
-2.33\end{array}$ & $\begin{array}{c}-0.172^{*} \\
-0.085^{*} \\
-0.123^{*} *\end{array}$ & $\begin{array}{l}-1.91 \\
-1.71 \\
-2.32 \\
\end{array}$ \\
\hline $\begin{array}{l}\text { Township characteristics } \\
\text { Gaogou town }(=1) \\
\text { Dougou town }(=1) \\
\text { Tanggou town }(=1)\end{array}$ & $\begin{array}{l}-0.097 \\
-0.099 \\
-0.103 \\
\end{array}$ & $\begin{array}{l}-1.60 \\
-1.54 \\
-1.56\end{array}$ & $\begin{array}{l}-0.077 \\
-0.135 \\
-0.121\end{array}$ & $\begin{array}{l}-0.87 \\
-1.42 \\
-1.23\end{array}$ \\
\hline $\begin{array}{l}\text { \# of observations } \\
\text { Predicted Prob (at X bar) } \\
\text { Observed frequency } \\
\text { Pseudo R }{ }^{2} \\
\text { Log pseudolikelihood }\end{array}$ & $\begin{array}{r}38 \\
21 \\
27 \\
0 . \\
-179\end{array}$ & & & \\
\hline
\end{tabular}

Notes: Standard errors are adjusted for clustering by households (201 households).

*: Significant at 10\%.**: significant at 5\%.***: significant at $1 \%$. 
Table 4 - Recursive bivariate probit estimates of being a return migrant and self-employment/higher ability job choice

\begin{tabular}{|c|c|c|c|c|}
\hline \multirow[t]{2}{*}{ Variables } & \multicolumn{2}{|c|}{ Model 1} & \multicolumn{2}{|c|}{ Model 2} \\
\hline & Coef. & Z-stat. & Coef. & Z-stat. \\
\hline \multicolumn{5}{|c|}{ Probability of being a self-employed or a high-ability worker } \\
\hline \multicolumn{5}{|l|}{ Individual characteristics } \\
\hline Return migrants & $1.111^{*}$ & 1.85 & $1.320 * * *$ & 2.81 \\
\hline Age (years) & $0.116^{*}$ & 1.78 & $0.267 * * *$ & 3.78 \\
\hline Age squared & $-0.001 * *$ & -2.03 & $-0.003 * * *$ & -3.75 \\
\hline Male $(=1)$ & $0.396 * *$ & 2.08 & $0.631 * * *$ & 3.39 \\
\hline Married (=1) & 0.668 & 1.60 & $0.927 * * *$ & 2.88 \\
\hline Education (years) & 0.004 & 0.14 & $0.105 * * *$ & 3.76 \\
\hline Child $(=1)$ & -0.169 & -0.37 & $1.819 * * *$ & 3.58 \\
\hline \multicolumn{5}{|l|}{ Household characteristics } \\
\hline \# children less than 6 & -0.245 & -1.10 & $-0.425^{*}$ & -1.89 \\
\hline \# children at school & -0.135 & -1.23 & $-0.200^{*}$ & -1.64 \\
\hline Land per person $(m u)$ & $-0.311 *$ & -1.86 & $-0.263 * *$ & -1.98 \\
\hline \multicolumn{5}{|l|}{ Township characteristics } \\
\hline Gaogou town $(=1)$ & $-0.402 *$ & -1.75 & -0.267 & -1.15 \\
\hline Dougou town $(=1)$ & -0.387 & -1.54 & -0.375 & -1.46 \\
\hline Tanggou town $(=1)$ & -0.426 & -1.61 & -0.362 & -1.39 \\
\hline Constant & $-3.008 * *$ & -2.21 & $-7.349 * * *$ & -4.57 \\
\hline
\end{tabular}

Probability of being a return migrant

\begin{tabular}{|c|c|c|c|c|}
\hline \multicolumn{5}{|l|}{ Individual characteristics } \\
\hline Age (years) & 0.109 & 1.64 & $0.117^{*}$ & 1.73 \\
\hline Age squared & $-0.002 * * *$ & -2.59 & $-0.002 * * *$ & -2.66 \\
\hline Male $(=1)$ & $0.396^{* *}$ & 2.27 & $0.393 * *$ & 2.24 \\
\hline Married(=1) & -0.157 & -0.32 & -0.226 & -0.45 \\
\hline Education (years) & -0.008 & -0.28 & -0.010 & -0.35 \\
\hline Child (=1) & -0.724 & -1.59 & -0.749 & -1.59 \\
\hline \multicolumn{5}{|l|}{ Household characteristics } \\
\hline \# children less than 6 & 0.021 & 0.10 & 0.032 & 0.14 \\
\hline \# children at school & -0.080 & -0.54 & -0.082 & -0.57 \\
\hline Land per person $(m u)$ & $-0.282 *$ & -1.58 & $-0.287^{*}$ & -1.61 \\
\hline \multicolumn{5}{|l|}{ Instruments } \\
\hline $\begin{array}{l}\text { \# of return migrants and migrants in } \\
\text { the household }\end{array}$ & $-0.018^{*}$ & -1.69 & $-0.018 *$ & -1.66 \\
\hline $\begin{array}{l}\text { \# of return migrants and migrants in } \\
\text { the village }\end{array}$ & $0.034 *$ & 1.70 & 0.032 & 1.61 \\
\hline Constant & -0.787 & -0.48 & -0.818 & -0.48 \\
\hline Rho & -0.47 & & -0.53 & \\
\hline Wald test of rho $=0$ : $\operatorname{chi} 2(1)$ & 1.24 & & 2.10 & \\
\hline Sample size & 384 & & 384 & \\
\hline Log pseudolikelihood & -350.52 & & -349.41 & \\
\hline
\end{tabular}


Table 5 - Transition matrix for pre-migration and post-return occupation of returnees

\begin{tabular}{|c|c|c|c|c|c|}
\hline \multirow{2}{*}{$\begin{array}{l}\text { Pre-migration } \\
\text { occupation }\end{array}$} & \multicolumn{5}{|c|}{ Post-return occupation } \\
\hline & Farm laborer & Manual worker & Skilled worker & Self-employed & Total \\
\hline Farm laborer & $\begin{array}{c}18 \\
(94.74 \%)\end{array}$ & $\begin{array}{c}5 \\
(41.67 \%)\end{array}$ & $\begin{array}{c}4 \\
(23.53 \%)\end{array}$ & $\begin{array}{c}17 \\
(44.74 \%)\end{array}$ & $\begin{array}{c}44 \\
(51.16 \%)\end{array}$ \\
\hline Manual worker & $\begin{array}{c}0 \\
(0.00 \%)\end{array}$ & $\begin{array}{c}1 \\
(8.33 \%)\end{array}$ & $\begin{array}{c}2 \\
(11.76 \%)\end{array}$ & $\begin{array}{c}4 \\
(10.53 \%)\end{array}$ & $\begin{array}{c}7 \\
(8.14 \%)\end{array}$ \\
\hline Skilled worker & $\begin{array}{c}0 \\
(0.00 \%)\end{array}$ & $\begin{array}{c}3 \\
(25.00 \%)\end{array}$ & $\begin{array}{c}4 \\
(23.53 \%)\end{array}$ & $\begin{array}{c}1 \\
(2.63 \%)\end{array}$ & $\begin{array}{c}8 \\
(9.30 \%)\end{array}$ \\
\hline Self-employed & $\begin{array}{c}0 \\
(0.00 \%)\end{array}$ & $\begin{array}{c}0 \\
(0.00 \%)\end{array}$ & $\begin{array}{c}2 \\
(11.76 \%)\end{array}$ & $\begin{array}{c}3 \\
(7.89 \%)\end{array}$ & $\begin{array}{c}5 \\
(5.81 \%)\end{array}$ \\
\hline Unemployed & $\begin{array}{c}1 \\
(5.26 \%)\end{array}$ & $\begin{array}{c}3 \\
(25.00 \%) \\
\end{array}$ & $\begin{array}{c}5 \\
(29.41 \%) \\
\end{array}$ & $\begin{array}{c}13 \\
(34.21 \%)\end{array}$ & $\begin{array}{c}22 \\
(25.58 \%) \\
\end{array}$ \\
\hline Total & $\begin{array}{c}19 \\
(22.09 \%) \\
\end{array}$ & $\begin{array}{c}12 \\
(13.95 \%) \\
\end{array}$ & $\begin{array}{c}17 \\
(19.77 \%) \\
\end{array}$ & $\begin{array}{c}38 \\
(44.19 \%) \\
\end{array}$ & $\begin{array}{c}86 \\
(100 \%) \\
\end{array}$ \\
\hline
\end{tabular}

Source: Wuwei 2008 Survey.

Note: Unemployed individuals before migration were students, house workers or waiting for a job. 
Table 6 - Return migrants' migration experience by occupational choice upon return

\begin{tabular}{|c|c|c|c|c|}
\hline & All & Self-employed & Non self-employed & Mean test \\
\hline \multicolumn{5}{|l|}{ Migration experience } \\
\hline \# job changes & $(0.09)$ & $(0.15)$ & $(0.09)$ & \\
\hline \multirow[t]{2}{*}{ \# city changes } & 1.88 & 2.03 & 1.77 & NS \\
\hline & $(0.20)$ & $(0.33)$ & $(0.24)$ & \\
\hline \multirow[t]{2}{*}{ \# years of migration } & 6.46 & 7.55 & 5.60 & $*$ \\
\hline & $(0.59)$ & $(0.82)$ & $(0.81)$ & \\
\hline \multirow[t]{2}{*}{ Age at first migration } & 26.49 & 24.66 & 27.94 & $*$ \\
\hline & $(0.92)$ & $(1.16)$ & $(1.35)$ & \\
\hline \multirow[t]{2}{*}{ Migration in or after the year 1996} & 0.55 & 0.42 & 0.65 & $* *$ \\
\hline & $(0.05)$ & $(0.08)$ & $(0.07)$ & \\
\hline \multirow[t]{2}{*}{ Repatriated savings (yuan) } & 11,933 & 16,263 & 8,504 & $* *$ \\
\hline & $(1574.62)$ & $(2797.18)$ & $(1609.89)$ & \\
\hline \multirow{2}{*}{$\begin{array}{l}\text { Worked in a big city during } \\
\text { migration }\end{array}$} & 0.59 & 0.61 & 0.58 & NS \\
\hline & $(0.053)$ & $(0.080)$ & $(0.072)$ & \\
\hline \multicolumn{5}{|l|}{ Post-return experience } \\
\hline \# years since return & $\begin{array}{c}5.12 \\
(0.51)\end{array}$ & $\begin{array}{c}5.71 \\
(0.76)\end{array}$ & $\begin{array}{c}4.64 \\
(0.68)\end{array}$ & NS \\
\hline \multirow[t]{2}{*}{ \# job changes upon return } & 1.28 & 1.42 & 1.17 & $* *$ \\
\hline & $(0.06)$ & $(0.11)$ & $(0.05)$ & \\
\hline \multirow[t]{2}{*}{ Age at return } & 34.49 & 33.53 & 35.25 & NS \\
\hline & $(1.05)$ & $(1.29)$ & $(1.57)$ & \\
\hline Sample size & 86 & 38 & 48 & \\
\hline
\end{tabular}

Source: Wuwei 2008 Survey.

Note: Standard errors in parentheses. 
Table 7 - Marginal effects for the probability of return migrants to be self-employed

\begin{tabular}{|c|c|c|c|c|}
\hline \multirow[t]{2}{*}{ Determinants of $P($ self) } & \multicolumn{2}{|c|}{ Standard Probit model } & \multicolumn{2}{|c|}{ IV Probit model } \\
\hline & $\begin{array}{c}\text { Marginal } \\
\text { effect }\end{array}$ & Z-stat. & $\begin{array}{c}\text { Marginal } \\
\text { effect }\end{array}$ & Z-stat \\
\hline $\begin{array}{l}\text { Individual \& family characteristics } \\
\text { Age (years) } \\
\text { Age squared } \\
\text { Male (=1) } \\
\text { Married (=1) } \\
\text { Education (years) } \\
\text { Land per person }(m u)\end{array}$ & $\begin{array}{c}0.094 \\
-0.001 * \\
0.177 \\
0.019 \\
0.002 \\
-0.111 \\
\end{array}$ & $\begin{array}{c}1.59 \\
-1.90 \\
1.37 \\
0.07 \\
0.06 \\
-0.78 \\
\end{array}$ & $\begin{array}{c}0.097 \\
-0.001 * \\
0.169 \\
0.043 \\
0.005 \\
-0.123 \\
\end{array}$ & $\begin{array}{c}1.56 \\
-1.84 \\
1.16 \\
0.13 \\
0.14 \\
-0.75\end{array}$ \\
\hline $\begin{array}{l}\text { Migration experience } \\
\text { \# of job changes during migration } \\
\text { Repatriated savings ( } 1,000 \text { yuan) } \\
\text { Worked in a big city during migration } \\
(=1) \\
\text { Return duration (years) }\end{array}$ & $\begin{array}{c}0.284^{* * *} \\
0.014^{*} \\
0.010 \\
\\
0.027^{*}\end{array}$ & $\begin{array}{l}2.73 \\
1.74 \\
0.07 \\
\\
1.67\end{array}$ & $\begin{array}{c}0.281^{* * *} \\
0.011 \\
0.021 \\
\\
0.026 \\
\end{array}$ & $\begin{array}{l}2.62 \\
0.45 \\
0.12 \\
\\
1.36\end{array}$ \\
\hline $\begin{array}{l}\text { Township characteristics } \\
\text { Gaogou town }(=1) \\
\text { Dougou town }(=1) \\
\text { Tanggou town }(=1)\end{array}$ & $\begin{array}{c}-0.439 * * * \\
-0.568^{* * *} \\
-0.406^{* * *} \\
\end{array}$ & $\begin{array}{l}-3.08 \\
-6.32 \\
-3.04 \\
\end{array}$ & $\begin{array}{l}-0.442 * * * \\
-0.564 * * * \\
-0.403 * * * \\
\end{array}$ & $\begin{array}{l}-3.06 \\
-5.69 \\
-2.82 \\
\end{array}$ \\
\hline $\begin{array}{l}\text { \# of observations } \\
\text { Pseudo } \mathrm{R}^{2} \\
\text { Log pseudolikelihood } \\
\text { Wald test of exogeneity }\end{array}$ & & & $\begin{array}{r}\varepsilon \\
-38 \\
\mathrm{Chi}^{2}(1 \\
\operatorname{Prob}>\mathrm{c}\end{array}$ & $\begin{array}{l}02 \\
0.90 \\
0.90\end{array}$ \\
\hline
\end{tabular}

Notes: *: Significant at 10\%. $* *$ : significant at 5\%. ${ }^{* * *}$ : significant at $1 \%$. 